\title{
\begin{tabular}{l|l|l} 
& Jurnal Kependidikan Dasar & Volume :4 \\
& Nomor :1 \\
\hline Tslam Berbasis Sains & Tahun :2019 \\
\hline
\end{tabular}
}

\section{Pengaruh Model Pembelajaran Scramble Dengan Media Question Card Terhadap Hasil Belajar IPA Siswa Kelas IV SDN Kertosari II Kabupaten Madiun}

\author{
Naniek Kusumawati \\ Program Studi PGSD, FKIP, Universitas PGRI Madiun \\ naniek@unipma.ac.id
}

\begin{abstract}
Abstrak
Kurang antusiasnya siswa dalam kegiatan pembelajaran mengakibatkan perlu dikembangkan model dan media pembelajaran yang efektif. Siswa merasa bosan dengan model pembelajaran konvensional yang sering digunakan guru. Dalam memilih model pembelajaran yang tepat haruslah memperhatikan kondisisiswa, sifat materi bahan ajar, fasilitas media yang tersedia. Model pembelajaran Scramble dengan media Question Card merupakan daya dukung utama bagi guru untuk menciptakan suasana belajar siswa secara aktif, menumbuhkan kreativitas dan semangat siswa untuk mempelajari materi-materi yang ada di dalamnya. Penelitian ini merupakan jenis penelitian True Eksperimental. Desain penelitian Postest Only Control desain. Subjek penelitian ini adalah siswa kelas IV sebanyak 48 siswa yang terdiri dari 24 siswa kelas IV eksperimen dan 24 siswa kelas kontrol. Penentuan sampel di dalam penelitian ini menggunakan simple random sampling. Pengumpulan data menggunakan teknik tes. Dalam menganalisis data menggunakan metode statistik dengan rumus uji-t dengan taraf signifikan $5 \%$. Hasil penelitian menunjukkan bahwa ada pengaruh signifikan model pembelajaran Scramble dengan media Question Card terhadap hasil belajar IPA siswa kelas IV SDN Kertosari II di Kabupaten Madiun. Ini terlihat pada hasil belajar nilai rata-rata siswa yang diajar menggunakan model tersebut 82,91 codangkan siswa yang diaiarkan dengan model konvensional 68,75 , serta diperoleh ${ }^{t_{\text {hitung }}}=6,074$, lebih besar dari ${ }^{t_{\text {tabel }}}=1,679$.
\end{abstract}

Kata Kunci : Model Pembelajaran Scramble, Media Question Card, Hasil Belajar IPA

\section{PENDAHULUAN}

Ilmu Pengetahuan Alam menurut Wonorahardjo $^{1}$ Ilmu pengetahuan alam adalah sekumpulan pengetahuan yang diperoleh melalui metode tertentu. Proses pencarian ini telah diuji kebenarannya secara bersama-sama oleh beberapa

\footnotetext{
1 Surjani Wonorahardjo, Dasar-Dasar Sains (Jakarta: Indeks, 2011), 12.
}

ahli. Bidang kajiannya diperlkan objektivitas dan kejelasan. Berusaha menguasai alam dan memanfaatkan alam untuk kesejahteraan manusia. Untuk membelajarkan siswa sesuai dengan gaya belajar mereka, maka guru diharapkan mampu menerapkan model pembelajaran yang inovatif. Oleh karena itu dalam memilih model pembelajaran yang tepat 
haruslah memperhatikan kondisi siswa, sifat materi bahan ajar, fasilitas media yang tersedia. Diharapkan dengan adanya model-model pembelajaran ini, guru atau tenaga pendidik dapak meningkatkan hasil belajar siswa dalam setiap kegiatan pembelajaran.

Salah satu permasalahan yang dihadapi pada proses pembelajaran di sekolah dasar khususnya mata pelajaran Ilmu Pengetahuan Alam (IPA) siswa kurang menarik mengikuti proses pembelajaran dalam kelas karena pola pembelajaran yang bersifat teacher centered. Guru masih sangat mendominasi pola pembelajaran. Terkadang guru membuat cacatan dipapan tulis lalu menerangkan dan kemudian memberikan tugas pada siswa. Siswa kurang diberikan ruang untuk mengkonstruksikan konsep yang abstrak melalui aktivitas yang nyata dalam kehidupan sehari-hari. Guru kurang tepat dalam menggunakan model pembelajaran. Pembelajaran IPA dikatakan menarik apabila pembelajaran yang dilaksanakan tersebut dapat mengaktifkan siswa. Guru tidak hanya sebagai sumber belajar namun siswa dituntut mencari sumber belajar lain. Sehingga proses pembelajaran tidak berjalan satu arah. Model pembelajaran adalah suatu perencanaan atau suatu pola yang digunakan sebagai pedoman dalam perencanaan dalam merencanakan pembelajaran di kelas atau pembelajaran dalam tutorial.

Model pembelajaran adalah kerangka konseptual yang menggambarkan prosedur sistematis dalam mengorganisasikan pengalaman belajar untuk mencapai tujuan belajar. Fungsi model pembelajaran adalah sebagai pedoman bagi perancang pengajaran dan para guru dalam melaksanakan pembelajaran. Pemilihan model pembelajaran sangat dipengaruhi oleh sifat dari materi yang akan diajarkan, tujuan yang akan dicapai dalam pembelajaran tersebut.

Hasil pengamatan peneliti menunjukkan bahwa pelaksanaan pembelajaran IPA berlangsung kurang optimal. Model pembelajaran yang digunakan guru masih bersifat konvesional. Kemampuan guru dalam menerapkan model pembelajaran tertentu masih kurang, serta kesulitan dalam pengelolaan kelas. Sebagian siswa tidak ikut serta dalam pembelajaran hanya siswa yang dominan saja yang memberikan kontribusi dalam proses pembelajaran. Hal tersebut disebabkan guru belum menerapkan model pembelajaran yang menuntut siswa aktif dan media pembelajaran yang digunakan guru kurang tepat sehingga siswa mudah bosan dalam pembelajaran serta berakibat pada hasil belajarnya. Agar siswa tidak merasa bosan maka guru harus senantiasa menggunakan model pembelajaran serta media pengajaran yang sesuai.

Media harus merangsang minat siswa dalam belajar. Media merupakan bagian integral dalam sistem pengajaran. Media diartikan sebagai segala sesuatu yang dapat digunakan untuk menyalurkan pesan, merangsang pikiran, perasaaan, perhatian dan kemauan siswa sehingga dapat mendorong proses belajar. Penggunaan media dan metode pembelajaran yang dipilih guru menerapkan salah satu cara meningkatkan kualitas pembelajaran. Peneliti dalam penelitiannya menggunakan media question card (kartu pertanyaan).

Media ini diharapkan mampu mengubah suasana belajar menjadi menarik dan mengaktifkan siswa. Question card merupakan kartu yang berisi sejumlah pertanyaan dengan menggunakan 
media ini bisa menumbuhkan tanggung jawab, kerjasama, persaingan sehat, dan keterlibatan belajar bagi peserta didik. Pada hasil penelitian Afifah ${ }^{2}$ menyatakan bahwa media question cards dapat dijadikan alternatif pembelajaran baru bagi guruguru, karena pembelajaran ini terbukti berpengaruh terhadap hasil kemampuan berpikir kreatif siswa. Hal ini dapat dilihat dari hasil belajar siswa, dimana kelas eksperimen memperoleh rata-rata nilai yang lebih baik dari pada kelas kontrol.

Berdasarkan permasalahan tersebut penelitian menentukan alternatif pemecahan masalah dengan memilih model pembelajaran yang tepat dan disesuaikan dengan materi maupun karakteristik anak sekolah dasar. Solusi pemecahannya dengan menerapkan Model Pembelajaran Scramble. Model Scramble merupakan model pembelajaran yang dipadukan dengan permainan yaitu permainan mengacak atau menyusun huruf menjadi jawaban yang benar. Hal ini sejalan dalam peneliatian John A. Bargh ${ }^{3}$ 'Stated that Scrambled Sentence Test' (Srull \& Wyer, 1979), presented to participants or student as a test of language ability, or devise letters become the right answer to construct a grammaticallycorrect contained an adjective or verb semantically related to the trait in question. Menyatakan bahwa kalimat acak (Srull \& Amp Wyer; , 1979), disampaikan kepada peserta atau mahasiswa sebagai uji kemampuan bahasa, atau menyusun huruf menjadi jawaban

\footnotetext{
2 Ni Putu Mita Ardani, I. Ketut Adnyana Putra, and MG Rini Kristiantari, "Pengaruh Kooperatif TGT Berbantuan Media Question Card Terhadap Hasil Belajar IPS Siswa Kelas V," Jurnal Mimbar PGSD Universitas Pendidikan Ganesha 2, no. 1 (2014): 10.

3 John A. Bargh, Mark Chen, and Lara Burrows, "Automaticity of Social Behaviour: Direct Effects of Trait Construct and Stereotype Activation on Action," Journal of Personality and Social Psychology 71, no. 2 (1996): 233-34.
}

yang benar untuk membangun sebuah tata bahasa yang benar terkandung. Peneliti mengkombinasikannya dengan media question card (kartu pertanyaan) kartu yang berisi pertanyaan akan memberikan kesan pembelajaran lebih menyenangkan.

Berdasarkan ulasan latar belakang tersebut diatas maka peneliti mengambil judul penelitian "Pengaruh Model Pembelajaran Scramble dengan Media Question Card Terhadap Hasil Belajar IPA Kelas IV SDN Kertosari II Kabupaten Madiun". Penelitian ini mengajukan hipotesis sebagai berikut: (1) ada pengaruh signifikan model pembelajaran scramble dengan media question card terhadap hasil belajarIPA siswa kelas IV SDN Kertosari II Kabupaten Madiun.

\section{A. KAJIAN TEORI \\ a. Pengertian Hasil Belajar}

Proses belajar yang dicapai oleh siswa dinyatakan dalam bentuk hasil belajar. Apalagi proses belajar bisa terjadi secara maksimal maka hasil belajar yang didapatkan juga maksimal. Menurut Susanto "hasil belajar yaitu perubahanperubahan yang terjadi pada diri siswa, baik yang menyangkut aspek kognitif, afektif, dan psikomotor sebagai hasil dari kegiatan belajar"4. Sedangkan hasil belajar menurut Rusman adalah sejumlah pengalaman yang diperoleh siswa mencakup ranah kognitif, afektif, dan psikomotor. Belajar tidak hanya pengusaan konsep teori mata pelajaran saja, tapi juga pengusaan kebiasaan, persepsi, kesenangan, minat-bakat, penyesuaian sosial, macam-macam keterampilan, citacita, keinginan dan harapan. ${ }^{5}$ Dari pendapat

\footnotetext{
4 Miftahul Huda, Model-Model Pengajaran Dan Pembelajaran (Yogyakarta: Pustaka Belajar, 2013), 5.

5 Rusman, Belajar Dan Pembelajaran Berbasis Komputer (Jakarta: Alfabet, 2013), 123.
} 
berbagai ahli diatas dapat disimpulkan bahwa hasil belajar adalah perubahan yang terjadi pada diri siswa, baik yang menyangkut aspek kognitif, afektif, dan psikomotor sebagai hasil dari kegiatan belajar. Serta ukuran keberhasilan siswa dalam mempelajari materi pelajaran di sekolah yang dinyatakan dalam skor yang diperoleh.

\section{b. Hakikat IPA}

Ilmu Pengetahuan Alam merupakan bagian dari ilmu Pengetahuan atau Sains yang semula berasal dari bahasa inggris'science'.Kata 'science'sendiriberasal dari kata dalam Bahasa latin 'scientia' yang berarti saya tahu. 'Science' terdiri dari social sciences (ilmu pengetahuan sosial) dan natural science (ilmu pengetahuan alam). Namun, dalam perkembangannya science sering diterjemahkan sebagai sains yang berarti Ilmu Pengetahuan Alam (IPA). ${ }^{6}$

Powler dalam Samatowa, bahwa IPA merupakan ilmu yang berhubungan dengan gejala alam dan kebendaan yang sistematis yang tersusun secara teratur, berlaku umum yang berupa kumpulan dari hasil observasi dan eksperimen/sistematis (teratur). Artinya pengetahuan itu tersusun dalam suatu sistem, tidak berdiri sendiri, saling berkaitan, saling menjelaskan sehingga seluruhnya merupakan kesatuan yang utuh. ${ }^{7}$

Dari penjelasan diatas dapat disimpulkan bahwa IPA adalah suatu kumpulan teori yang sistematis, penerapannya secara umum terbatas pada gejala-gejala alam, lahir dan berkembang melalui metode ilmiah seperti observasi dan eksperimen. Mempelajari fenomena

\footnotetext{
6 Trianto, Model Pembelajaran Terpadu (Jakarta: Bumi Aksara, 2014), 136.

7 Usman Samatowa, Pembelajaran IPA Di Sekolah Dasar (Jakarta: PT. Indeks, 2010), 3.
}

alam yang faktual (factual), baik berupa kenyataan atau kejadian dan hubungan sebab akibatnya.

\section{c. Model Pembelajaran Scramble 1) Pengertian Model Pembelajaran Scramble}

Menurut Shoimin Scramble merupakan model pembelajaran yang mengajak siswa untuk menemukan jawaban. Serta menyelesaikan permasalahan yang ada dengan cara membagikan lembar soal dan lembar jawaban yang disertai dengan alternatif jawaban yang tersedia. ${ }^{8}$

\section{2) Langkah-langkah Pembelajaran Model Scramble}

Sintak pembelajaran Scramble menurut Huda dapat diterapkan dengan mengikuti tahap-tahap berikut ini.

a) Guru menyajikan materi sesuai topik, misalnya guru menyajikan materi pelajaran tentang "Energi".

b) Setelah menjelaskan tentang Energi, guru membagikan lembar kerja dengan jawaban yang diacak susunannya.

c) Guru memberi durasi tertentu untuk pengerjaan soal.

d) Siswa mengerjakan soal berdasarkan waktu yang telah ditentukan guru.

e) Guru mengecek durasi waktu sambil memeriksa pekerjaan siswa.

f) Jika waktu pengerjaan soal sudah habis, siswa wajib mengumpulkan lembar jawaban kepada guru. Dalam hal ini, baik siswa yang selesai maupun tidak selesai harus mengumpulkan jawaban itu.

g) Guru melakukan penilaian, baik di kelas maupun di rumah. Penilaian dilakukan berdasarkan seberapa cepat siswa

\footnotetext{
8 Aris Shoimin, 68 Model Pembelajaran Inovatif Dalam Kurikulum 2013 (Yogyakarta: Ar-Ruzz Media, 2016), 166.
} 
mengerjakan soal dan seberapa banyak soal yang ia kerjakan dengan benar.

h) Guru memberi apresiasi dan rekognisi dengan siswa yang berhasil, dan memberi semangat kepada siswa yang belum cukup berhasil menjawab dengan cepat dan benar.

Setiap model pembelajaran memiliki kelebihan dan kelemahan tersendiri sama halnya dengan model pembelajaran scramble. Menurut Shoimin kelebihan dari model pembelajaran scramble adalah:

a) Setiap anggota kelompok bertanggung jawab atas segala sesuatu yang dikerjakan dalam kelompoknya. Serta melatih kekompokan antar siswa.

b) Model pembelajaran ini memungkinkan siswa untuk saling belajar sambil bermain. Mereka dapat berkreasi sekaligus belajar dan berpikir, mempelajari sesuatu secara santai dan tidak membuat mereka stres.

c) Melatih keterampilan tertentu juga dapat memupuk rasa solidaritas.

d) Materi yang diberikan melalui salah satu metode permainan biasanya mengesankan dan sulit dilupakan.

e) Sifat kompetitif dan mendorong siswa berlomba-lomba untuk maju. Sehingga adanya kemampuan untuk bersaing dalam proses pembelajaran. Membuat siswa lebih tertarik pada setiap kegiatan belajar berlangsung.

Sedangkan kelemahan model pembelajaran scramble adalah:

a) Pembelajaran ini terkadang sulit dalam merencanakannya karena terbentur dengan kebiasaan siswa dalam belajar. terkadang kebiasaan siswa dalam belajar tidak bisa ditebak dan berubah-ubah.

b) Terkadang dalam mengimplementasikannya, memerlukan waktu yang panjang sehingga guru sulit menyesuaikan dengan waktu yang telah ditentukan.

c) Selama kriteria keberhasilan belajar ditentukan oleh kemampuan siswa menguasai materi pelajaran, pembelajaran akan sulit diimplementasikan guru.

d) Menimbulkan suara gaduh hal ini jelas mengganggu kelas yang berdekatan. Sering proses pembelajaran yang terjadi tidak efektif. ${ }^{9}$

\section{d. Question Card (Kartu Pertanyaan)}

Question card atau kartu soal merupakan media visual yang berupa kertas berukuran 10 X $10 \mathrm{~cm}$. Isi dari kartu ini yaitu sebagian berisi soal-soal tentang materi yang akan diajarkan. ${ }^{10}$ Question Cards adalah pertandingan yang dilakukan oleh kelompok siswa dengan menjawab pertanyaan berupa kartu. Penggunaan media kartu ini merupakan sarana yang fungsi utamanya sebagai alat bantu untuk melakukan kegiatan pembelajaran. Siswa ditugaskan menjawab pertanyaan yang terdapat dalam kartu soal untuk menambah poin.

Dapat disimpulkan bahwa pengertian question card adalah kartu soal yang berisi soal-soal tentang materi yang akan diajarkan yang fungsi utamanya sebagai alat bantu untuk melakukan kegiatan pembelajaran.

\section{METODE PENELITIAN}

Metode penelitian yang digunakan dalam penelitian ini adalah kuantitatif dengan bentuk Quasi Experimental Design. Menurut Sugiono bentuk desain eksperimen ini merupakan pengembangan dari true eksperimen design, yang sulit

9 Shoimin, 168.

${ }^{10}$ Ardani, Putra, and Kristiantari, "Pengaruh Kooperatif TGT Berbantuan Media Question Card Terhadap Hasil Belajar IPS Siswa Kelas V," 4. 
dilaksanakan. Desain ini mempunyai kelompok kontrol, tetapi tidak dapat berfungsi sepenuhnya untuk mengontrol variabel-variabel luar yang mempengaruhi pelaksanaan eksperimen. Metode ini digunakan karena dalam penelitian ini berusaha menemukan ada atau tidaknya pengaruh penggunaan Model Pembelajaran Scramble dengan media Question Card terhadap hasil belajar IPA siswa kelas IV SDN Kertosari II Kabupaten Madiun. ${ }^{11}$

\section{Variabel penelitian}

Menurut Arikunto menyatakan bahwa variabel adalah objek penelitian, atau apa ynag telah menjadi titik perhatian suatu penelitian. ${ }^{12}$ Selain itu pendapat lain menyatakan bahawa variabel penelitian adalah suatu atribut atau sifat atau nilai dari orang, obyek, organisasi atau kegiatan yang mempunyai variasi tertentu yang ditetapkan oleh peniliti untuk dipelajari dan kemudian ditarik kesimpulan. ${ }^{13}$

Variabel dalam penelitian ini menurut sifatnya dapat diklasifikasikan menjadi: 1. Variabel Bebas disebut juga variabel stimulus, predictor, antecedent. Dalam bahasa Indonesia sering disebut sebagai variabel bebas. Variabel bebas adalah meruakan variabel yang mempengaruhi atau yang menjadi sebab perubahannya atau timbulnya variabel dependen (terikat). ${ }^{14}$ Variabel bebas (X) dalam penelitian ini adalah model pembelajaran scramble dengan media question card, 2. Variabel Terikat sering disebut sebagai variabel output, kriteria, konsekuensi. Dalam bahasa Indonesia sering disebut

\footnotetext{
11 Sugiyono, Metode Penelitian Manajemen, vol. 2 (Bandung: Alfabeta, 2015), 114.

12 Suharsimi Arikunto, Prosedur Penelitian (Jakarta: Rineka Cipta, 2010), 161.

13 Sugiyono, Metode Penelitian Manajemen (Cetakan Ke-1) (Bandung: Alfabeta, 2013), 38.

1496.
}

sebagai variabel terikat. Variabel terikat merupakan variabel yang dipengaruhi atau yang menjadi akibat, karena adanya variabel bebas. ${ }^{15}$ Variabel terikat (Y) dalam penelitian ini adalah hasil belajar IPA siswa kelas IV SDN Kertosari II Kabupaten Madiun.

\section{Desain Penelitian}

Desain penelitian yang digunakan dalam penelitian ini adalah PosttestOnly Control Design. Desain penelitian ini digunakan pelaksanaan penelitian yang dilakukan pada dua kelompok, kelompok 1 mendapatkan perlakuan model pembelajaran Scrambel dengan media Question Card, dan kelompok 2 mendapatkan pembelajaran konvensional. Penelitian ini digunakan untuk mengetahui perbedaan hasil belajar akibat perlakuan yang diberikan, yaitu melalui pengaruh penggunaan model pembelajaran scramble dengan media question card terhadap hasil belajar siswa kelas IV SDN Kertosari Kabupaten Madiun.

Dalam penelitian ini, peneliti bertujuan membandingkan kedua model pembelajaran dengan menggunakan dua kelas yaitu kelas IV A sebagai kelas eksperimen yang diberi perlakuan menggunakan model scramble dengan media question card sedangan kelas IV B sebagai kelas kontrol yang diberi perlakuan dengan model pembelajaran konvensional. Hal ini bermaksud untuk mengetahui perbedaan model scramble dengan media question card dengan model konvensional terhadap hasil belajar IPA siswa kelas IV SDN Kertosari II. Populasi adalah wilayah generalisasi yang terdiri atas obyek/ subyek yang mempunyai kualitas dan karakteristik tertentu yang ditetapkan oleh 
peneliti untuk dipelajari dan kemudian ditarik kesimpulannya. Pada penelitian ini yang menjadi populasi penelitian adalah siswa kelas IV SDN Kertosari II. Sampel pada penelitian ini adalah siswa kelas IV A dan siswa kelas IV B SDN Kertosari II Kabupaten Madiun.

\section{Teknik Pengambilan sampel}

Teknik pengambilan sampel pada penelitian ini adalah menggunakan teknik simple random sampling. Teknik simple random sampling merupakan teknik pengambilan sampel yang dilakukan secara acak tanpa memerhatikan strata yang ada dalam populasi tersebut Berdasarkan keterangan tersebut maka sampel dipilih dengan menggunakan undian sebagai penentuan kelas eksperimen dan kelas kontrol. Setelah diundi kelas yang menjadi kelas eksperiman adalah kelas IV A dan kelas yang menjadi kelas kontrol kelas IV B.

\section{Teknik Pengumpulan Data}

Teknik pengumpulan data dalam penelitian ini adalah tes. Tes pada penelitian ini berbentuk tes tertulis pada soal pilihan ganda yang memuat beberapa soal megenai materi pelajaran IPA.

\section{Instrumen Penelitian}

Instrumen yang digunakan dalam penelitian ini berupa Soal untuk memperoleh data tentang hasil belajar IPA siswa. Instrumen dengan menggunakan soal yang berupa lembar soal pilihan ganda dengan tujuan untuk mengetahui dan mengukur hasil belajar siswa kelas IV SDN Kertosari II Kabupaten Madiun. Pada penelitian ini menggunakan tes pilihan ganda (multiple choice). Siswa diminta untuk memilih salah satu jawaban yang dianggap paling benar dari pokok bahasan energi dan kegunaannya. Instrument yang digunakan harus dilakukan uji validasi terlebih dahulu yaitu:

a. Uji validitas tes hasil belajar

Cara pengujian instrument dalam penelitian ini dengan menggunakan validitas ini (content validity). Secara teknis validitas isi dapat dibantu dengan menggunakan kisi-kisi instrument. Uji validitas menggunakan korelasi Product Moment yang rumusnya secara lengkap sebagai berikut ${ }^{16}$

b. Uji Reliabilitas Tes

Reliabilitas berasal dari kata reliability berarti sejauh mana hasil suatu pengukuran dapat dipercaya. Suatu hasil pengukuran hanya dapat dipercaya apabila dalam beberapa kali pelaksanaan pengukuran terhadap kelompok yang sama diperoleh hasil pengukuran yang sama. Reliabilitas menunjuk pada satu pengertian bahwa sesuatu instrumen cukup dapat dipercaya untuk digunakan sebagai alat pengumpul data karena instrumen tersebut sudah baik. Instrumen yang baik tidak akan bersifat tendensius mengarahakan responden untuk memilih jawaban-jawaban tertentu. ${ }^{17}$

\section{Teknik Analisis Data}

Analisis data merupakan kegiatan setelah data dari seluruh responden atau sumber data lain terkumpul. Sebelum melakukan analisis data, terlebih dahulu harus melalui uji prasyarat data yakni uji normalitas, uji homogenitas dan uji hipotesis. Uji normalitas dengan metode Liliefors digunakan jika datanya tidak dapat distribusi frekuensi data bergolong. Uji homogenitas digunakan untuk

\footnotetext{
16 Anas Sudijino, Pengantar Evaluasi Pendidikan (Jakarta: Rajawali Press, 2009), 181.

17 Arikunto, Prosedur Penelitian, 221.
} 
mengetahui apakah variansi-variansi dari sejumlah sampel yang homogen atau tidak. Uji homogenitas data penelitian ini menggunakan uji F. Uji hipotesis pada penelitian ini yaitu menggunakan uji $t$ atau t-test. Untuk testing signifikansi, maka digunakan $t$-test.

\section{HASIL PENELITIAN}

Berdasarkan data hasil belajar siswa kelas eksperimen dan kelas kontrol dapat diketahui mengenai perbandingan nilai rata-rata tes hasil belajar IPA siswa kelas eksperimen dan kelas kontrol. Kelas eksperimen memperoleh nilai rata-rata 82,91 sementara siswa pada kelas kontrol memperoleh nilai dibawah kelas eksperimen yaitu 68,71. Dari hasil tersebut dapat disimpulkan bahwa kelas eksperimen yang diajar dengan menggunakan model pembelajaran Scramble dengan media Question Card lebih unggul dari kelas kontrol yang diajar secara konvensional. Hal tersebut dikarenakan pada kelas eksperimen diberi perlakuan model pembelajaran Scramble dengan media Question Card lebih unggul dari kelas kontrol tidak diberi perlakuan model pembelajaran Scramble dengan media Question Card. Pada pembelajaran ini siswa dapat berfikir secara mandiri dan lebih tertarik dengan proses pembelajaran yang. Siswa lebih mudah untuk memahami materi yang disampaikan. Pada pembelajaran tanpa menggunakan model Scramble dengan media Question card atau secara konvensional, siswa kurang antusias untuk mengikuti pembelajaran karena pembelajaran hanya mendengar dan menulis sehingga siswa merasa bosan dengan pembelajaran, yang mengakibatkan tujuan pembelajaran tidak dapat tersampaikan dengan baik.
Penelitian menggunakan uji $\mathrm{t}$ yang harus melalui uji prasyarat yaitu uji normaitas dan homogenitas data. Data yang digunakan merupakan data nominal sehingga menggunakan statistik non parametris untuk menganalisis data tersebut.

\section{Hasil Uji Prasyarat}

Uji prasyarat meliputi uji normalitas dan homogenitas. Data yang dipakai adalah data dari hasil tes nilai siswa kelas IVB (kelas kontrol) dan kelas IVA (kelas eksperimen) SDN kertosari II dengan jumlah soal tes hasil belajar 20 soal. Berikut adalah hasil uji Normalitas dan Homogenitas.

a. Uji Normalitas

Pada penelitian ini, peneliti menggunakan rumus; Liliefors dengan taraf signifikasi $\alpha=0,05$. Daerah kritik pada uji liliefors adalah $D K=\left\{\mathrm{LlL}>\mathrm{L}_{0.05 ; \mathrm{n}}\right\}$.

Kriteria ujinya adalah sebagai berikut:

Ho diterima jika $\mathrm{L}_{\text {obs }}<\mathrm{L}_{\text {tabel }}$

Ha diterima jika $\mathrm{L}_{\text {obs }}>\mathrm{L}_{\text {tabel }}$

1) Hasil Belajar Uji Normalitas

Dibawah ini adalah hasil uji normalitas untuk hasil belajar pada kelas eksperimen dan kelas kontrol. Terangkum pada tabel di bawah ini: Tabel Rangkuman Hasil Uji Normalitas Hasil Belajar

\begin{tabular}{lccll}
\hline \multicolumn{1}{c}{ Kelas } & $\mathbf{L}_{\mathrm{obs}}$ & $\mathbf{L}_{\text {tabel }}$ & Keputusan & Kesimpulan \\
\hline Kelas Kontrol & 0,1474 & 0,176 & $\mathrm{H}_{\mathrm{o}}$ diterima & $\begin{array}{l}\text { Berdistribusi } \\
\text { normal }\end{array}$ \\
\hline $\begin{array}{l}\text { Kelas } \\
\text { Eksperimen }\end{array}$ & 0,1443 & 0,176 & $\mathrm{H}_{\mathrm{o}}$ diterima & $\begin{array}{l}\text { Berdistribusi } \\
\text { normal }\end{array}$ \\
\hline
\end{tabular}

Berdasarkan tabel hasil belajar uji normalitas diatas terlihat bahwa pada kelas eksperimen $\mathrm{L}_{\text {obs }}(0,1443)<\mathrm{L}_{\text {tabel }}$ $(0,176)$ maka $\mathrm{H}_{\mathrm{o}}$ diterima, sehingga data yang diperoleh dari kelas eksperimen berasal dari populasi yang berdistribusi normal Pada kelas kontrol $\mathrm{L}_{\text {obs }}\left(0,1474<\mathrm{L}_{\text {tabel }}(0,176)\right.$ 
maka $\mathrm{H}_{\mathrm{o}}$ diterima, berarti data pada kelas kontrol tersebut berasal dari populasi yang berdistribusi normal.

b. Uji Homogenitas

Uji homogenitas digunakan dengan tujuan untuk mengetahui sama atau tidaknya variansi-variansi dari sejumlah populasi. Peneliti menguji homogenitas kelas IVB (kelas kontrol) dan kelas IVA (kelas eksperimen) SDN Kertosari II Kabupaten Madiun dengan menggunakan rumus uji $\mathrm{F}$.

Data diperoleh dari nilai tes hasil belajar siswa kelas eksperimen dan kontrol yang digunakan untuk mencari homogenitas kedua kelas tersebut.Uji homogenitas untuk mengetahui variansi-variansi dari sejumlah populasi sama atau tidak. Statistik uji yang digunakan adalah uji F. Dengan taraf signifikasi $=0,05$ dari data hasil tes siswa disajikan dalam tabel berikut:

Tabel Rangkuman Hasil Analisis Uji Homogenitas

\begin{tabular}{llll}
\hline$F_{\text {hitung }}$ & $F_{\text {tabel }}$ & Kriteria & Keputusan Uji \\
\hline 1,191 & $F_{0,05.24}$ & $F_{\text {hitung }}$ & HoHo \\
& $F_{0,05.24}=$ & $F_{\text {hitung }}$ & diterima \\
& 2,014 & $\leq F_{\text {tabel }}$ & \\
& & $\leq F_{\text {tabel }}$ & \\
\hline
\end{tabular}

Dari tabel diatas dapat dilihat bahwa hasil uji homogenitas berdasarkan nilai sebelum perlakuan dan nilai sesudah perlakuan diperoleh $F_{\text {hitung }}$ $F_{\text {hitung }}=1,191$ sedangkan $F_{\text {tabel }} F_{\text {tabel }}=$ 2.014. Dengan kriteria nengujian $H_{1} H_{1}=$ $F_{\text {hitung }} \leq F_{\text {tabel }} F_{\text {hitung }} \leq F_{\text {tabel }}, 1,191 \leq \leq$

2,014. Ini berarti Ho diterima, sehingga dapat disimpulkan sampel berasal dari populasi yang memiliki varians homogen.

\section{Uji Hipotesis}

Setelah dilakukan uji normalitas dan homogenitas diketahui bahwa subjek penelitian darikelas eksperimendankontrol berasal dari populasi yang berdistribusi normal dan populasinya bersifat homogen. Oleh karena itu, uji hipotesis untuk melihat apakah ada pengaruh dari model pembelajaran Scramble dengan media Question Card terhadap hasil belajar IPA pada siswa di kelas eksperimen dengan hasil belajar IPA siswa kelas kontrol yang menggunakan metode konvensional dapat dihitung dengan menggunakan rumus uji-t.

Tabel Rangkuman Analisis Uji-t untuk hasil belajar IPA

\begin{tabular}{cccc}
\hline Variabel & $\mathrm{T}_{\text {obs }}$ & $\mathrm{T}_{\text {tabel }}$ & Keputusan \\
\hline Hasil & 6,074 & 1,679 & Ha diterima \\
Belajar IPA & & & \\
\hline
\end{tabular}

Berdasarkan hasil analisis data tes hasil belajar (danat dilihat pada lampiran) diperoleh $t_{\text {hitung }} t_{\text {hitung }}=6,074$, lebih besar dari $t_{\text {tabel }} t_{\text {tabel }}=1,679$, sehingga dapat disimpulkan bahwa penggunaan model pembelajaran Scramble dengan media Question Card berpengaruh terhadap hasil belajar IPA siswa kelas IV SDN Kertosari II Kabupaten Madiun.

\section{PEMBAHASAN}

Dari hasil peneilitian yang dilakukan bahwa pengaruh penggunaan model pembelajaran Scramble dengan media Question Card terhadap hasil belajar IPA kelas IV SDN Kertosari II Kabupaten Madiun. Model pembelajaran Scramble dengan media Question Card siswa terbiasa menyelesaikan tugas mandiri karena semua siswa dapat ikut serta berperan aktif dalam proses pembelajaran yang sedang berlangsung. Siswa dapat mengeksplorasi pengetahuan mereka dalam proses pembelajaran tanpa harus 
terpaku pada penjelasan guru. Sedangkan pada pembelajaran yang menggunakan model dan media konvensional, siswa kurang tertarik dan merasa bosan karena siswa hanya menerima materi dari buku yang ada.

Hal ini dikarenakan siswa lebih antusias dalam menerima materi pembelajaran jika menggunakan model dan media yang menarik. Bahan pelajaran yang menarik minat siswa, lebih mudah dipelajari dan disimpan karena minat menambah kegiatan belajar. Minat dalam diri siswa dapat dibangun dengan membawakan pelajaran dengan cara yang berbeda yang merangsang rasa keingin tahuan siswa dan dikemas secara inovatif, kreatif dan menyenangkan. Karena pada dasarnya siswa dalam perkembangan usia SD sangat senang dengan kegiatan yang tidak hanya mengenai kognitif tetapi juga aspek psikomotor siswa. Sehingga pembelajaran tidak hanya duduk diam dikursi mendengarkan penjelasan guru, namun siswa dapat berdiri, berlari, berbicara, diskusi, dan menyanyi, namun tetap dalam batasan proses pembelajaran yang kondusif.

Hamalik mengemukakan bahwa pemakaian media pembelajaran dalam proses belajar mengajar dapat membangkitkan keinginan dan minat yang baru, membangkitkan motivasi dan rangsangan keinginan belajar, dan bahkan membawa pengaruh-pengaruh psikologis terhadap siswa. Penggunaan media pembelajaran akan menjadikan pembelajaran berlangsung dengan efektif. ${ }^{18}$

Saat penelitian menggunakan model Scramble dengan media Question Card pada

\footnotetext{
18 Muhammad Yamin, Desain Pembelajaran Berbasis Tingkat Satuan Pendidikan, vol. 1 (Jakarta: Gaung Persada Press, 2007), 15.
}

mata pelajaran IPA kelas IV SDN Kertosari II Kabupaten Madiun, siswa belajar dengan aktif dengan selalu memberikan respon terhadap pertanyaan yang diajukan oleh guru dan memperhatikan pembelajaran. Selain itu siswajuga aktifdalam penggunaan media Question Card yang telah disediakan oleh peneliti menurut kelompoknya.

Setelah pembelajaran menggunakan model pembelajaran Scramble dengan media Question Card, peneliti menggunakan tes hasil belajar IPA untuk melihat tingkat keberhasilan belajar siswa. Pasca pembelajaran menggunakan model pembelajaran Scramble dengan media Question Card dilakukan analisis terhadap data yang diperoleh dari tes hasil belajar IPA kelas IV SDN Kertosari II Kabupaten Madiun. Berdasarkan perhitungan data diperoleh dari kelas kontrol yang tidak diberi perlakuan model pembelajaran Scramble dengan media Question Card nilai terendah $=50$ dan nilai tertinggi 80 , mean $=68,75$. Sedangkan kelas eksperimen yang diberi perlakuan model pembelajaran Scramble dengan media Question Card diperoleh nilai terendah $=70$ dan nilai tertinggi 95 , mean $=82,91$. Nilai rata-rata tersebut berada di atas KKM yaitu 75 . Meskipun ada 1 siswa yang masih dibawah KKM karena memang kurang aktif dalam pembelajaran dan sulit memahami materi .

Dari pembahasan diatas menunjukkan terdapat perbedaan yang positif dan signifikan antara kelas yang diajar dengan menggunakan model Scramble dengan kelas yang diajar secara konvensional.

\section{KESIMPULAN DAN SARAN}

\section{Kesimpulan}

Berdasarkan hasil analisis data dan pembahasan dalam penelitian ini, maka dapat disimpulkan tentang pengaruh 
penggunaan model pembelajaran Scramble dengan media Question Card terhadap hasil belajar IPA siswa kelas IV SDN Kertosari II Kabupaten Madiun diketahui bahwa siswa lebih antusias dalam proses pembelajaran. Terbukti pada saat kegiatan belajar berlangsung semua siswa ikut aktif dan tidak didominasi oleh beberapa siswa saja. Selain hasil belajar yang meningkat minat belajar siswa pun juga ikut meningkat, siswa dapat menggali kemampuannya sendiri melalui model pembelajaran scramble dengan media question card sehingga melatih siswa untuk berfikir secara aktif dan mandiri.

\section{Saran}

Berdasarkan kesimpulan di atas, maka saran yang diberikan peneliti adalah sebagai berikut:

1. Bagi Guru

Guru perlu mengembangkan model pembelajaran Scramble dengan Question Card dalam pembelajaran untuk pokok bahasan lain yang sesuai sehingga hasil belajar siswa menjadi lebih baik.

2. Bagi Peneliti Lain

Peneliti yang akan mengadakan penelitian yang serupa hendaknya menggunakan sampel, materi ataupun mata pelajaran yang berbeda sehingga dapat diketahui tingkat konsistensi pengaruh pembelajaran Scramble dengan Question Card terhadap hasil belajar IPA siswa.

\section{DAFTAR PUSTAKA}

Ardani, Ni Putu Mita, I. Ketut Adnyana Putra, and MG Rini Kristiantari. "Pengaruh Kooperatif TGT Berbantuan Media Question Card Terhadap Hasil Belajar
IPS Siswa Kelas V." Jurnal Mimbar PGSD Universitas Pendidikan Ganesha 2, no. 1 (2014).

Arikunto, Suharsimi. Prosedur Penelitian. Jakarta: Rineka Cipta, 2010.

Bargh, John A., Mark Chen, and Lara Burrows. "Automaticity of Social Behaviour: Direct Effects of Trait Construct and Stereotype Activation on Action." Journal of Personality and Social Psychology 71, no. 2 (1996): 230.

Huda, Miftahul. Model-Model Pengajaran Dan Pembelajaran. Yogyakarta: Pustaka Belajar, 2013.

Rusman. Belajar Dan Pembelajaran Berbasis Komputer. Jakarta: Alfabet, 2013.

Samatowa, Usman. Pembelajaran IPA Di Sekolah Dasar. Jakarta: PT. Indeks, 2010.

Shoimin, Aris. 68 Model Pembelajaran Inovatif Dalam Kurikulum 2013. Yogyakarta: Ar-Ruzz Media, 2016.

Sudijino, Anas. Pengantar Evaluasi Pendidikan. Jakarta: Rajawali Press, 2009.

Sugiyono. Metode Penelitian Manajemen. Vol. 2. Bandung: Alfabeta, 2015.

-_- Metode Penelitian Manajemen (Cetakan Ke-1). Bandung: Alfabeta, 2013.

Trianto. Model Pembelajaran Terpadu. Jakarta: Bumi Aksara, 2014.

Wonorahardjo, Surjani. Dasar-Dasar Sains. Jakarta: Indeks, 2011.

Yamin, Muhammad. Desain Pembelajaran Berbasis Tingkat Satuan Pendidikan. Vol. 1. Jakarta: Gaung Persada Press, 2007. 